\title{
PERBEDAAN ASUPAN ZAT GIZI PADA LANSIA ANEMIA DAN NON ANEMIA
}

\author{
Teguh Wicaksono, Etika Ratna Noer \\ Program Studi Ilmu Gizi Fakultas Kedokteran Universitas Diponegoro \\ Jl.Dr.Sutomo No.18, Semarang, Telp (024) 8453708, Email : gizifk@undip.ac.id
}

\begin{abstract}
Background : Nutritional anemia is the other nutritional problems in elderly related to deficient intakes of protein, folate, vitamin $B_{12}$, iron, zinc, and vitamin $C$. Anemia's incidence in elderly was correlated with impairment of cognitive, physical function, and also increasing the risk of death. This study aims to analyze the difference of nutrients intake among anemic and non anemic elderly.

Methods : This was a cross-sectional study. Subjects were elderly women aged 60 - 70 years old which selected using consecutive sampling method. Hemoglobin level was measured using cyanmethemoglobin method. Nutrients intake were calculated using Food Frequency Questionnaire (FFQ).

Results : Subjects in this study were 61 person. Anemic group were 13 subjects $(21,32 \%)$ and non anemic group were 48 subjects $(78,68 \%)$. Mean of Intake of protein, folate, vitamin $B_{12}$, zinc, and vitamin $C$ in anemic group were lower than non anemic group, while there was no difference in mean different of iron intake. Folate and zinc intakes among both groups were insufficient. Statically, there was significant difference of protein and vitamin $B_{12}$ intake among both groups $(p<0,05)$, while there was no significant difference of iron, vitamin $C$, folate, and zinc intake intakes among both groups. $(p>0,05)$.

Conclusions : Folate and zinc intake among both group were insufficient. There was significant difference of protein and vitamin $B_{12}$ intake among both groups, while there was no significant difference of iron, vitamin $C$, folate, and zinc intake among both groups.
\end{abstract}

Keyword : nutrient intake, elderly, anemia, protein, folat, vitamin B12, besi, zinc, vitamin C

\begin{abstract}
ABSTRAK
Latar Belakang : Anemia gizi merupakan salah satu masalah gizi yang sering dialami oleh lansia berkaitan dengan defisiensi asupan protein, folat, vitamin $B_{12}$, besi, zinc, dan vitamin $C$. Kejadian anemia pada lansia berdampak terhadap penurunan fungsi kognisi, kinerja fisik, dan peningkatan risiko kematian. Penelitian ini bertujuan untuk menganalisis perbedaan asupan zat gizi pada lansia anemia dan non anemia.

Metode : Penelitian ini menggunakan rancangan cross-sectional. Subjek penelitian adalah lansia wanita berusia 60 - 70 tahun yang dipilih menggunakan tehnik consecutive sampling. Kadar hemoglobin diukur menggunakan metode cyanmethemoglobin. Asupan zat gizi dihitung menggunakan metode Food Frequency Questionnaire (FFQ).

Hasil : Subjek penelitian berjumlah 61 orang. Kelompok anemia berjumlah 13 orang (21,32\%) dan kelompok non anemia berjumlah 48 orang $(78,68 \%)$. Rerata asupan protein, folat, vitamin $B_{12}$, zinc, dan vitamin C kelompok anemia lebih rendah dibandingkan kelompok non anemia, sedangkan rerata asupan besi kedua kelompok tidak berbeda. Asupan folat dan zinc kedua kelompok tidak terpenuhi. Secara statisitik, asupan protein dan vitamin $B_{12}$ kedua kelompok menunjukkan perbedaan signifikan ( $p<0,05)$, sedangkan asupan besi, vitamin $C$, folat, dan zinc tidak menunjukkan perbedaan signifikan ( $p>0,05)$.

Simpulan : Asupan folat dan zinc kedua kelompok tidak terpenuhi. Asupan protein dan vitamin $B_{12}$ kedua kelompok menunjukkan perbedaan signifikan, sedangkan asupan besi, vitamin $C$, folat dan zinc tidak menunjukkan perbedaan signifikan.
\end{abstract}

Kata kunci : asupan zat gizi, lansia, anemia, protein, folat, vitamin B12, besi, zinc, vitamin C

\section{PENDAHULUAN}

Salah satu masalah kesehatan yang sering dialami oleh lansia adalah anemia. ${ }^{1}$ Kejadian anemia pada lansia secara signifikan berhubungan dengan kejadian penurunan fungsi kognisi, kinerja fisik, dan peningkatan risiko kematian. ${ }^{2-5}$ Jenis anemia yang sering dialami oleh lansia adalah anemia gizi. Kejadian anemia gizi berhubungan dengan defisiensi asupan folat, vitamin $B_{12}$, dan besi, dimana absorpsi besi juga dapat dipengaruhi oleh defisiensi protein, zinc, dan vitamin $\mathrm{C}$, serta bahan makanan sumber tannin, fitat, dan oksalat yang dikonsumsi bersamaan dengan makanan utama.

Hasil penelitian yang dilakukan Semba dkk di Amerika Serikat menyatakan bahwa proporsi kejadian anemia defisiensi besi pada lansia wanita mencapai $15 \%$, sedangkan di Indonesia, proporsi kejadian anemia pada lansia mencapai $50 \%{ }^{6,7}$ Hasil penelitian yang dilakukan oleh Thompson dkk menyatakan bahwa asupan protein, folat, vitamin $B_{12}$, dan besi pada lansia 
wanita anemia lebih rendah dibandingkan asupan pada lansia wanita tidak anemia. ${ }^{8}$ Hasil penelitian lain menyatakan bahwa kadar hemoglobin $(\mathrm{Hb})$ lansia wanita berusia di atas 70 tahun berkurang sebanyak $0,036 \mathrm{~g} / \mathrm{dL}$ per tahun. ${ }^{9}$

Salah satu tolak ukur kemajuan suatu bangsa dapat dilihat dari usia harapan hidup penduduknya. ${ }^{10}$ Pada tahun 2009 , usia harapan hidup lansia di Indonesia mencapai 67,5 tahun, sedangkan pada tahun 2010, meningkat menjadi 70,9 tahun. Hal ini berdampak terhadap peningkatan proporsi penduduk lansia. Peningkatan ini diharapkan dapat berkesinambungan dengan konsep healthy aging yang merupakan dasar dan tujuan dilakukannya penelitian terhadap lansia. Peningkatan sarana pelayanan kesehatan seperti posyandu lansia merupakan salah satu upaya menuju kondisi healthy aging. Dinas Kesehatan Kota Semarang melaporkan bahwa angka kejadian anemia pada lansia di wilayah kerja Puskesmas Gajahmungkur tahun 2011 cukup tinggi. Berdasarkan latar belakang tersebut, peneliti tertarik untuk meneliti perbedaan asupan gizi pada lansia anemia dan non anemia.

\section{METODE}

Penelitian dilaksanakan pada bulan Desember 2012 hingga Januari 2013 di Posyandu Lansia Kelurahan Petompon, Sampangan, Bendan Duwur, dan Karang Rejo Kecamatan Gajahmungkur. Penelitian ini termasuk dalam lingkup gizi masyarakat dan merupakan penelitian observasional menggunakan desain cross sectional.

Subjek penelitian adalah lansia wanita yang dipilih menggunakan tehnik consecutive sampling dengan kriteria sehat, berusia $60-70$ tahun, dapat beraktivitas secara mandiri, dan bersedia menjadi subjek penelitian setelah mengisi informed consent.

Data yang dikumpulkan meliputi identitas subjek, kadar hemoglobin ( $\mathrm{Hb}$ ), asupan energi, karbohidrat, lemak, protein, folat, vitamin $\mathrm{B}_{12}$, besi, zinc dan vitamin C. Kelompok anemia diketahui setelah dilakukan pengukuran kadar $\mathrm{Hb}$ menggunakan metode cyanmethemoglobin. Subjek dikategorikan dalam kelompok anemia apabila kadar $\mathrm{Hb}<12 \mathrm{~g} / \mathrm{dL}$ dan non anemia apabila kadar $\mathrm{Hb} \geq 12 \mathrm{~g} / \mathrm{dL}$. Pengukuran kadar $\mathrm{Hb}$ dilakukan oleh analis kesehatan Balai Laboratorium Kesehatan Provinsi Jawa Tengah.

Asupan zat gizi subjek selama tiga bulan diperoleh melalui proses wawancara menggunakan metode Food Frequency Questionnaire (FFQ). Data yang diperoleh kemudian diolah menggunakan alat bantu software komputer. Asupan energi, karbohidrat, lemak dan protein dikategorikan kurang jika asupan $<100 \%$ kebutuhan dan lebih jika asupan $>100 \%$ kebutuhan. Pengkategorian ini didasarkan pada kebutuhan zat gizi individu perhari. Asupan folat, vitamin $\mathrm{B}_{12}$, besi, zinc dan vitamin C dikategorikan berdasarkan Angka Kecukupan Gizi (AKG) tahun 2004 untuk orang Indonesia. Asupan folat perhari dikategorikan rendah jika $<400 \mu \mathrm{g}$ dan cukup jika $400-1000 \mu \mathrm{g}$. Asupan vitamin $B_{12}$ perhari dikategorikan rendah jika $<2,4 \mu \mathrm{g}$ dan cukup jika $\geq 2,4 \mu \mathrm{g}$. Asupan besi perhari dikategorikan rendah jika $<8 \mathrm{mg}$ dan cukup jika 8 - $45 \mathrm{mg}$. Asupan zinc perhari dikategorikan rendah jika $<9,8 \mathrm{mg}$ dan cukup jika 9,8 - $40 \mathrm{mg}$. Asupan vitamin $\mathrm{C}$ perhari dikategorikan rendah jika $<75 \mathrm{mg}$ dan cukup jika 75 -1000 mg.

Uji normalitas yang digunakan adalah uji Saphiro Wilk. Jika data berdistribusi normal, digunakan uji beda Independent t-test, sedangkan apabila data tidak berdistribusi normal, digunakan uji beda Mann - Whitney.

\section{HASIL PENELITIAN}

Subjek penelitian berjumlah 61 orang. Kelompok anemia berjumlah 13 orang $(21,32 \%)$ dan kelompok non anemia berjumlah 48 orang $(78,68 \%)$.

Distribusi frekuensi asupan zat gizi pada kelompok anemia dan non anemia dapat dilihat pada tabel 1.

Tabel 1. Distribusi frekuensi asupan zat gizi

\begin{tabular}{lcccc}
\hline & \multicolumn{2}{c}{ Anemia $(\mathrm{n}=13)$} & \multicolumn{2}{c}{ Non Anemia $(\mathrm{n}=48)$} \\
\cline { 2 - 5 } & $\mathrm{n}$ & $\%$ & $\mathrm{n}$ & $\%$ \\
\hline Asupan energi $(\mathrm{kkal}) *$ & 4 & 30,8 & 5 & 10,4 \\
Kurang & 9 & 69,2 & 43 & 89,6 \\
Lebih & & & & \\
\hline Asupan karbohidrat $(\mathrm{g}) *$ & 11 & 84,6 & 15 & 31,2 \\
Kurang & 2 & 15,4 & 33 & 68,8 \\
Lebih & & &
\end{tabular}




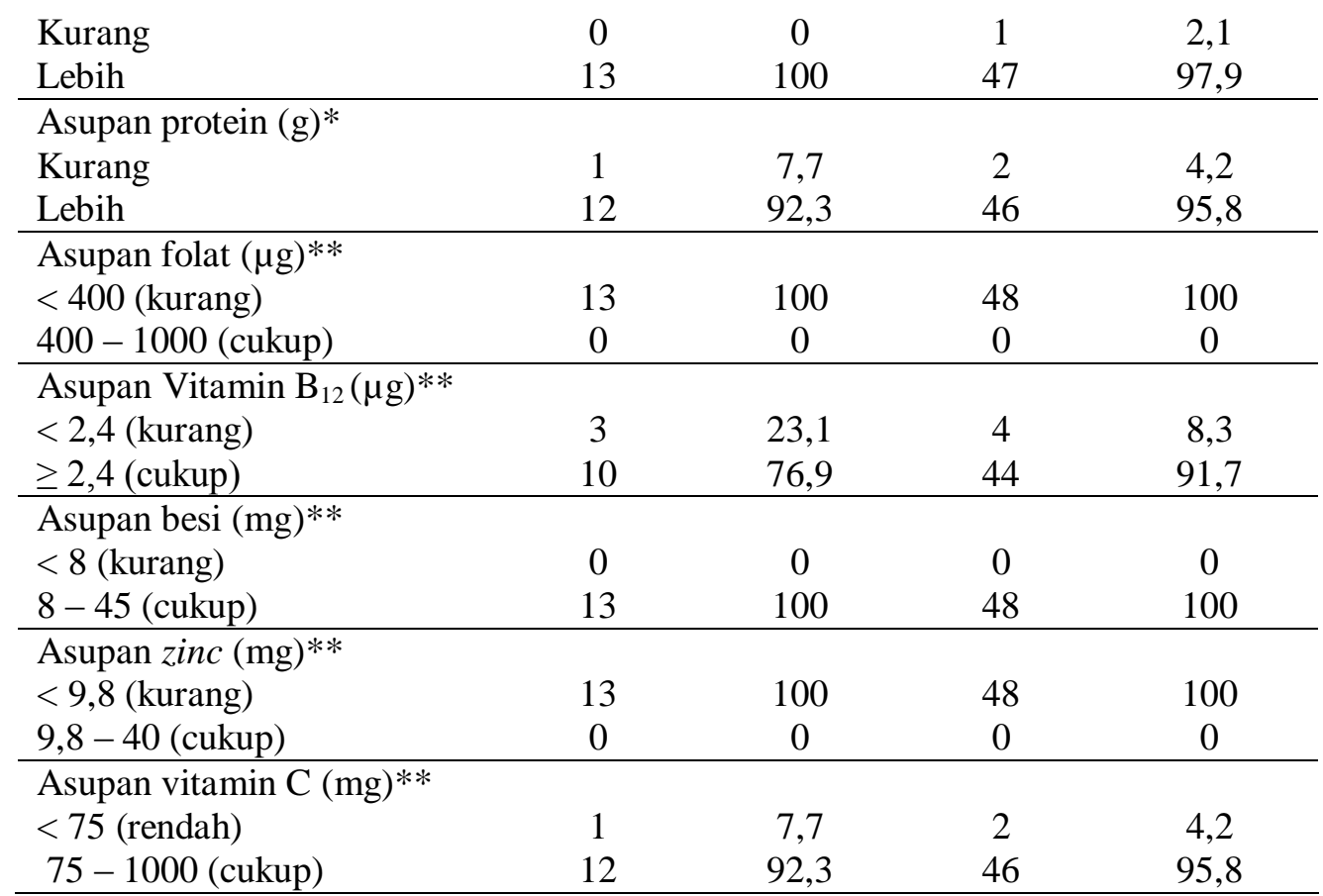

*dihitung berdasarkan kebutuhan individu perhari. **dihitung berdasarkan AKG.

Berdasarkan tabel 1, diketahui bahwa asupan energi dan protein kedua kelompok sebagian besar berada dalam kategori lebih. Asupan karbohidrat kelompok anemia sebagian besar berada dalam kategori kurang, sedangkan asupan karbohidrat kelompok non anemia sebagian besar berada dalam kategori lebih. Asupan lemak kedua kelompok berada dalam kategori lebih. Asupan vitamin $B_{12}$, besi, dan vitamin $C$ kedua kelompok sebagian besar berada dalam kategori cukup, Sedangkan asupan folat dan zinc kedua kelompok berada dalam kategori kurang.

Berdasarkan pengkajian asupan zat gizi, diketahui bahwa subjek pada kedua kelompok mengkonsumsi makanan sumber karbohidrat seperti nasi sebanyak dua kali sehari. Subjek pada kelompok anemia mengkonsumsi bahan makanan (produk hewani) sumber protein, vitamin $\mathrm{B}_{12}$, besi, dan zinc seperti telur ayam, ikan, dan daging merah lebih sedikit dibandingkan subjek pada kelompok non anemia. Subjek pada kedua kelompok mengkonsumsi bahan makanan (produk nabati) sumber protein dan besi seperti tahu dan tempe minimal satu kali dalam sehari. Subjek pada kedua kelompok juga mengkonsumsi sayur dan buah yang merupakan bahan makanan sumber folat, dan vitamin $\mathrm{C}$ masing - masing minimal satu hari sekali dan tiga kali seminggu. Sayur dan buah yang paling banyak dikonsumsi oleh kedua kelompok yaitu terong, kol, bayam, pisang, dan pepaya.

Perhitungan nilai minimum, maksimum, rerata, simpang baku, dan penilaian uji statistik asupan zat gizi dapat dilihat pada tabel 2 .

Tabel 2. Nilai minimum, maksimum, rerata, dan simpang baku asupan zat gizi

\begin{tabular}{|c|c|c|c|c|c|c|c|}
\hline & \multicolumn{3}{|c|}{ Anemia $(n=13)$} & \multicolumn{3}{|c|}{ Non Anemia $(n=48)$} & \multirow[b]{2}{*}{$p$} \\
\hline & Min & Mak & Rerata \pm SB & Min & Mak & Rerata $\pm S B$ & \\
\hline Energi (kkal) & $\begin{array}{c}1517, \\
7\end{array}$ & $\begin{array}{c}1972 \\
6\end{array}$ & $\begin{array}{c}1726,2 \pm 142 \\
5\end{array}$ & $\begin{array}{c}1467, \\
8\end{array}$ & $\begin{array}{c}2508, \\
6\end{array}$ & $\begin{array}{c}1977,2 \pm 22 \\
8\end{array}$ & $\begin{array}{c}0,001 * \\
*\end{array}$ \\
\hline Karbohidrat (g) & 174,8 & 230,3 & $199,8 \pm 14,9$ & 169,6 & 320,1 & $246,8 \pm 37,9$ & $\begin{array}{l}0,001^{*} \\
*\end{array}$ \\
\hline Lemak $(\mathrm{g})$ & 70,5 & 89,3 & $79,1 \pm 5,5$ & 57,47 & 97,5 & $77,5 \pm 8,9$ & 0,539 \\
\hline Protein (g) & 52,3 & 89,3 & $70,2 \pm 10,5$ & 55,3 & 98,7 & $78 \pm 8,9$ & $\begin{array}{c}0,009^{*} \\
*\end{array}$ \\
\hline Folat $(\mu \mathrm{g})$ & 176,8 & 347,2 & $236,1 \pm 43,1$ & 150,1 & 338,1 & $253,6 \pm 51,9$ & 0,269 \\
\hline$\underset{(\mu \mathrm{g})^{*}}{\text { Vitamin }^{*}}$ & 1 & 7,8 & $3,2 \pm 1,7$ & 1 & 11,4 & $4,6 \pm 1,9$ & $\begin{array}{c}0,006^{*} \\
*\end{array}$ \\
\hline
\end{tabular}




$\begin{array}{cccccccc}\text { Besi (mg) } & 14,7 & 23,1 & 19,4 \pm 2,2 & 12,8 & 24,5 & 19,4 \pm 2,7 & 0,963 \\ \text { Zinc (mg) } & 5,8 & 8,7 & 7,5 \pm 0,9 & 5,4 & 9,6 & 7,9 \pm 0,9 & 0,233 \\ \text { Vitamin C } & 70,4 & 184,1 & 110,2 \pm 31,6 & 64,8 & 290,3 & 118,6 \pm 35,3 & 0,498 \\ (\mathrm{mg}) * & & & & \end{array}$

Uji beda independent $t-$ test. $*$ Uji Mann - Whitney. ** signifikan $(p<0,05)$

Berdasarkan tabel 2, diketahui bahwa rerata asupan energi, karbohidrat, protein, folat, vitamin $\mathrm{B}_{12}$, zinc, dan vitamin $\mathrm{C}$ kelompok anemia lebih rendah dibandingkan rerata asupan kelompok non anemia, sedangkan rerata asupan lemak kelompok anemia lebih tinggi dibandingkan rerata asupan kelompok non anemia. Sementara itu, rerata asupan besi kedua kelompok tidak berbeda. Berdasarkan perhitungan statistik, dapat diinterpretasi bahwa terdapat perbedaan signifikan pada asupan energi $(p=0,001)$, karbohidrat $(p=0,001)$, protein $(p=$ $0,009)$, dan vitamin $\mathrm{B}_{12}(p=0,006)$ pada kedua kelompok, sedangkan asupan besi, vitamin $\mathrm{C}$, folat, dan zinc kedua kelompok tidak menunjukkan perbedaan signifikan.

\section{PEMBAHASAN}

Variabel asupan zat gizi makro (karbohidrat, lemak, protein) diukur menggunakan kebutuhan individu perhari. Pengukuran dengan perhitungan kebutuhan individu perhari mengakibatkan asupan zat gizi makro kedua kelompok tidak dapat berada tepat di angka $100 \%$.

Pada penelitan diketahui bahwa asupan karbohidrat dan protein kedua kelompok menunjukkan perbedaan signifikan $(p<0,05)$. Bahan makanan yang banyak mengandung karbohidrat adalah bahan makanan pokok seperti beras. Pada penelitian diketahui bahwa asupan kedua kelompok terhadap bahan makanan tersebut berada dalam kategori kurang. Perbedaan asupan karbohidrat diduga akibat subjek pada kelompok non anemia mengkonsumsi bahan makanan yang juga mengandung karbohidrat selain nasi lebih banyak dibandingkan kelompok anemia. Perbedaan asupan protein diakibatkan subjek pada kelompok non anemia mengkonsumsi bahan makanan hewani lebih banyak dibandingkan kelompok anemia.

Asupan lemak tidak menunjukkan perbedaan signifikan $(p>0,05)$. Asupan lemak tidak berbeda dikarenakan makanan yang dikonsumsi oleh kedua kelompok sebagian besar diolah dengan metode goreng dan tumis. Salah satu fungsi lemak dalam makanan adalah menambah rasa gurih. Rasa gurih ini membantu mengatasi masalah defisiensi asupan zat gizi pada lansia akibat penurunan ketajaman indera pengecap. ${ }^{1}$
Variabel asupan zat gizi mikro (folat, Vitamin B12, besi, zinc, vitamin C) diukur dan dibandingkan dengan Angka Kecukupan Gizi (AKG) untuk lansia wanita.

Pada penelitian diketahui bahwa asupan folat kedua kelompok tidak menunjukkan perbedaan signifikan $(p>0,05)$. Selain itu, asupan folat kedua kelompok tidak terpenuhi. Bahan makanan sumber folat adalah sayuran hijau. ${ }^{11}$ Asupan folat tidak terpenuhi disebabkan asupan sayuran hijau kedua kelompok berada dalam kategori kurang. Jenis sayur yang banyak dikonsumsi oleh kedua kelompok adalah sayur sop dan lodeh.

Berbeda dengan hasil penelitian ini, hasil penelitian yang dilakukan oleh Tucker dkk menyatakan bahwa asupan folat pada lansia di Amerika telah terpenuhi. Bahan makanan sumber folat yang dikonsumsi di negara tersebut adalah bahan makanan yang sudah difortifikasi dengan folat seperti tepung gandum, tepung terigu, dan sereal. Selain meningkatkan asupan folat, makanan yang difortifikasi dengan folat juga mudah diabsorbsi karena sudah berada dalam bentuk aktifnya (pteroilmonoglutamat). ${ }^{12,13}$

Pada penelitan diketahui bahwa asupan vitamin B12 kedua kelompok menunjukkan perbedan signifikan $(p<0,05)$. Perbedaan asupan vitamin $\mathrm{B}_{12}$ terjadi akibat sebagian besar kelompok anemia mengkonsumsi bahan makanan sumber vitamin $B_{12}$ yaitu produk - produk hewani seperti telur ayam, ikan, dan daging merah lebih sedikit dibandingkan kelompok non anemia. Walaupun menunjukkan perbedaan signifikan, nilai rerata asupan vitamin $B_{12}$ kelompok anemia masih berada dalam kategori cukup $(3,2 \pm 1,7)$.

Kejadian anemia akibat defisiensi vitamin $B_{12}$ jarang terjadi. ${ }^{14}$ Sebuah penelitian menyatakan bahwa defisiensi asupan vitamin $\mathrm{B}_{12}$ tidak mempengaruhi kadar serum vitamin $B_{12}$ yang merupakan indikator utama anemia akibat defisiensi vitamin $\mathrm{B}_{12}{ }^{15}$ Hasil penelitian lain yang dilakukan oleh Kwak dkk di Korea menyatakan bahwa walaupun asupan vitamin $\mathrm{B}_{12}$ lansia dari bahan makanan hewani sebagian besar berada dalam kategori kurang, konsentrasi serum vitamin $\mathrm{B}_{12}$ tidak mengalami penurunan. Bahan makanan yang dikonsumsi oleh subjek dalam penelitian 
Kwak adalah bahan makanan hasil fermentasi seperti kimchi dan kecap. ${ }^{16}$

Pada penelitan diketahui bahwa asupan besi kedua kelompok tidak menunjukkan perbedaan signifikan $(p>0,05)$. Hal ini terjadi diduga akibat subjek pada kedua kelompok mengkonsumsi tempe dan tahu dengan jumlah yang hampir sama. Tempe dan tahu merupakan bahan makanan yang "populer" di kalangan masyarakat Indonesia dan memiliki kandungan besi yang cukup tinggi. Pada 100 gram tempe terkandung 4 gram besi dan pada 100 gram tahu terkandung 3,4 gram besi. ${ }^{17}$ Hal ini mengakibatkan asupan besi kedua kelompok berada dalam kategori cukup. Rerata asupan besi kelompok anemia $(19,4 \pm 2,2)$ tidak berbeda dibandingkan rerata asupan besi kelompok non anemia $(19,4 \pm 2,7)$.

Pada penelitan diketahui bahwa asupan zinc kedua kelompok tidak menunjukkan perbedaan signifikan $(p>0,05)$. Selain itu, asupan zinc kedua kelompok tidak terpenuhi. Bahan makanan sumber zinc adalah bahan makanan produk hewani dan serealia (nasi). ${ }^{11}$ Walaupun bahan makanan produk hewani lebih banyak mengandung zinc, pada beberapa negara yang menggunakan nasi sebagai makanan pokok, defisiensi zinc jarang terjadi. ${ }^{14} \mathrm{Hal}$ ini dipertegas dengan hasil penelitian di Jepang yang menyatakan bahwa bahan makanan yang paling banyak berkontribusi terhadap pemenuhan zinc sehari adalah bahan makanan pokok seperti beras dan produk olahannya, kemudian susu, daging, dan ikan. ${ }^{18}$ Asupan zinc tidak terpenuhi disebabkan asupan bahan makanan produk hewani dan nasi pada kedua kelompok berada dalam kategori kurang.

Pada penelitan diketahui bahwa asupan vitamin $\mathrm{C}$ kedua kelompok tidak menunjukkan perbedan signifikan $(p>0,05)$. Hal ini terjadi diduga akibat subjek pada kedua kelompok mengkonsumsi bahan makanan sumber vitamin $\mathrm{C}$ seperti buah - buahan dalam jumlah dan jenis yang relatif sama. Buah yang dikonsumsi oleh sebagian besar subjek pada kedua kelompok adalah pisang dan papaya. Walaupun tidak berbeda signifikan, rerata asupan vitamin $\mathrm{C}$ kelompok anemia $(110,2 \pm 31,6)$ lebih rendah dibandingkan rerata asupan vitamin $\mathrm{C}$ kelompok non anemia $(118,6 \pm 35,3)$.

Pada penelitian ini, penyebab kejadian anemia pada subjek tidak dapat diketahui secara pasti, tetapi jika ditinjau dari penelitian - penelitian sebelumnya, kejadian anemia gizi pada lansia erat hubungannya dengan defisiensi status besi dan vitamin $B_{12}$ dalam tubuh. Keterbatasan asupan makanan menjadi salah satu penyebab anemia gizi pada lansia. Selain anemia gizi dan anemia akibat penyakit, lansia juga sering mengalami anemia yang penyebabnya belum dapat diidentifikasi secara pasti, sehingga sering disebut sebagai unexplained anemia. ${ }^{19}$

\section{KETERBATASAN PENELITIAN}

Keterbatasan dalam penelitian ini yaitu menggunakan metode yang mengandalkan daya ingat subjek, sehingga dapat terjadi bias saat pengumpulan data.

\section{SIMPULAN}

Asupan folat dan zinc kedua kelompok tidak berbeda signifikan dan tidak terpenuhi. Secara statistik, asupan protein dan vitamin $B_{12}$ kedua kelompok menunjukkan perbedaan signifikan, sedangkan asupan besi dan vitamin C tidak menunjukkan perbedaan signifikan.

\section{SARAN}

Perlu dilakukan penelitian lebih lanjut mengenai intervensi yang dapat dilakukan untuk memenuhi asupan folat dan zinc pada lansia.

\section{UCAPAN TERIMA KASIH}

Puji syukur penulis haturkan kehadirat Allah SWT, atas segala rahmat dan kemudahan yang telah diberikan-Nya. Ucapan terima kasih ditujukan kepada kader Posyandu Lansia Kelurahan Petompon, Sampangan, Bendan Duwur, dan Karang Rejo Kecamatan Gajahmungkur; responden yang berpartisipasi dalam penelitian; Ibu Etika Ratna Noer, S.Gz, M.Si, Prof. Dr. M. Sulchan, M.Sc DA Nutr, Sp.GK, dan dr Aryu Chandra K., M.kes. epid. atas saran dan bimbingannya dalam penyusunan karya tulis ilmiah ini.

\section{DAFTAR PUSTAKA}

1. Siti Fatimah Muis, Niken Puruhita. Gizi pada Lansia. In : H. Hadi martono, Kris Panaka, editors. Buku Ajar Ilmu Geriatri (Ilmu Kesehatan Usia Lanjut) $4^{\text {th }}$ ed. Jakarta. 2009.p.626;3.

2. Hagino T, Ochial S, Sato E, Maekawa S, Wako M, Haro H. The Relationship Between Anemia at Admission and Outcome in Patients Older than 60 Years with Hip Fracture. J Orthopaed Traumatol. 2009;10:119-122.

3. Lucca U, Tettamanti M, Moscoin P, Apolone G, Gandini F, Nabili A, et al. Association of Mild Anemia with Cognitive, Functional Mood and 
Quality of Life Outcomes in the Elderly: The "Health and Anemia" Study. Plos One.2008;3(4).

4. Thein M, Ershler WB, Artz AS, Tecson J, Robinson BE, Rothstein G, et al. Diminished Quality of Life and Physical Function in Community Dwelling Elderly with Anemia. Medicine (Baltimore). 2009;88(2):103-114.

5. Sheth TN, Choundry NK, Bowes, Detsky A. The Relation of Conjunctival Pallor to The Presence of Anemia. J Gen Intern Med. 1997;12(2):102 - 6.

6. Semba RD, Ricks MD, Fermei L, Li XQ, Chares P, Fried LP, Guaranik JM. Type of Anemia and Mortality Among Older Disabled Women Living in the Community; The Women's Health and Aging Study. Aging Clin Exp Res. 2007.19(4):259-264.

7. Departemen Kesehatan RI. Studi Morbiditas: Data Survei Kesehatan Rumah Tangga 2002-2003. Badan Litbangkes. 2003.

8. Thomson CA, Stanaway J, Neuhouser ML, Snetselaar LG, Stefanick ML, Arendell L, Chen Z. Nutrient intake and Anemia Risk in the WHI Observational Study. J Am Diet Assoc. 2011. 111(4): 532;541.

9. Yamada M, Wong FL, Suzuki G. Longitudinal trends of Hemoglobin Levels in a Japanaese Population-RERF's Adult Healthy study Project. Eur J Haematol. 2003;70:129-35.

10. R. Boedhi Darmojo. Teori Proses Menua. In : R. Boedhi Darmojo, H. Hadi Martono, editors. Buku Ajar Geriatri (Ilmu Kesehatan Usia Lanjut) $3^{\text {rd }}$ ed. Jakarta. Balai Penerbit FKUI; 2006.p.3:13

11. Ball GFM. Vitamins in Food; Analysis, Bioavailbilty, and Stability. United States: CRC Press. 2006.p231 -305.

12. Tucker KL, Selhub J, Wilson Pwf, Rosenburg IWH. Dietary Intake Pattern Relates to Plasma Folate and Homocysteine in The Framingharm Heart Study. J Nutr. 1996; 126: 3023 -3031.

13. Gropper SS, Smith JL, Groff JL. Advanced Nutrition and Human Metabolism $5^{\text {th }}$ ed. United States: Wadsworth. 2009.p.348-357.

14. Thompson JL, Manore MM, Vaughan LA. The Science of Nutrition. United States: Pearson Education Inc. 2011.p.447-470

15. Howard JM, Azen C, Jacobsen DW, Green R, Carmel R. Dietary intake of cobalamin in elderly people who have abnormal serum cobalamin, methylmalonic acid and homocystein levels. Eur J Clin Nutr 1998;52:582-7.

16. Kwak Chung shil, Lee Mee Sook, Lee Hae Jeung, Whang Jin Yong, Park Sang Chul. Dietary Source of Vitamin $\mathrm{B}_{12}$ Intake and Vitamin $\mathrm{B}_{12}$ Status in Female Elderly Koreans Aged 85 and Older Living in Rural Area. Nutr Res Pract. 2010;4(3):229-234.

17. Persatuan Ahli Gizi Indonesia. Tabel Komposisi Pangan Indonesia. Jakarta. Elex Media Komputindo. 2009.

18. Sarukura N, Kogirima M, Takai S, Kitamura Y,Kalubi B, Yamamoto S, Takeda N. Dietary Zinc
Intake and Its Effect on Zinc Nutrition in Healthy Japanese Living in the Central of Japan. Journal of Medical Investigation. 2011.

19. Kanapuru B, Artz AS, Ershler WB. Erythropoietin Deficiency and Late-Life Anemia. In : Balducci L, Ershler WB, Bennett JM, editors. Anemia in the Elderly. United States. Springer. 2007.p.115-123. 